\title{
MEASURING ZAKAT IMPACT ON POVERTY AND WELFARE USING CIBEST MODEL
}

\author{
Irfan Syauqi Beik ${ }^{1}$ \\ Laily Dwi Arsyianti ${ }^{2}$
}

\begin{abstract}
This research attempts to analyze the role of productive-based zakat program in reducing poverty level of mustahik (zakat recipient) households from the perspective of material and spiritual dimensions. The study utilizes primary data which is obtained from interview through questionnaire in DKI Jakarta and Bogor Regency. 221 respondents are selected and interviewed as research samples. They are zakat beneficiaries managed by BAZIS DKI Jakarta and Dompet Dhuafa. The primary data collection was conducted on February until May 2015. CIBEST model comprising four indices is used as tool of analysis. These indices are welfare index, material poverty index, spiritual poverty index and absolute poverty index. It is found that the presence of zakat utilization program is able to increase welfare index of the mustahik by 96.8 percent. The material poverty index and absolute poverty index can also be reduced by 30.15 percent and 91.30 percent, respectively. Unpredictable result occurs on spiritual poverty index in which there is an increase of two households living under spiritual poverty. It means that these two zakat recipient households suffer weakening spiritual values despite materially better-off in the presence of zakat program.
\end{abstract}

Keywords: CIBEST model, Poverty, Productive-based zakat program

JEL Classification: 0150, R290, Z120, Z190

1 Director, Center of Islamic Business and Economic Studies (CIBEST), Bogor Agricultural University (IPB), Indonesia. Email: irfan_beik@ipb.ac.id

2 Lecturer of Islamic Economics Study Program, Department of Economics, Faculty of Economics and M anagement, Bogor A gricultural University (IPB), Indonesia. She is currently PhD student at the Institute of Islamic Banking and Finance (IIBF), International Islamic University M alaysia. Email: arsyianti@apps.ipb.ac.id 


\section{INTRODUCTION}

Poverty remains one of the major problems faced by most of the developing countries including Indonesia. A number of policies have been introduced in many countries in order to alleviate poverty and income inequality. However, global target to reduce the number of poverty incidence by half in the year 2015 as declared by the UN Summit in 2000 seems to fail. Continuous global financial crises affecting the performance of global economy seem to be one of the main causes of this failure.

In the context of Indonesia, despite reduction trend of the number of the poor takes place in the country for the last decade, the target to lower the number of the poor from 15 percent of the total population in 2003 to 7.5 percent in 2015 may not be achieved. This could be observed from the official statistical data published by the Central Board of Statistics (Badan Pusat Statistik abbreviated as BPS) in which the number of the poor in Indonesia as of March 2015 still equals 11.22 percent from total population (BPS, 2015).

This situation should encourage the government to utilize all domestic resources to overcome the problem of poverty and income inequality. The presence of zakat in this regard finds its significance. As social and economic instrument, zakat basically has huge potential that can be optimized for the development of a nation (Qardawi, 2011). Based on the study conducted by Firdaus et al. (2012) it is found that zakat potential in Indonesia reaches Rp217 trillions or equivalent with 3.40 percent of the Indonesia's GDP in 2010. Realization of this potential will be highly depending upon the presence of professional and trustable zakat institutions operating in the country.

Currently Indonesia has implemented Zakat Management Act No 23/2011 that replaces Zakat Management Act No 38/1999 as legal foundation for the operation of zakat institutions. The Act divides zakat institution into two types, i.e. The National Board of Zakat (Badan Amil Zakat Nasional abbreviated as BAZNAS) and private zakat institutions (Lembaga Amil Zakat abbreviated as LAZ), which must be approved and accredited by government (M inistry of Religious Affairs) in order to operate. BAZNAS, according to the Act, is given the authority to manage and to coordinate all zakat institutions 
comprising BAZNAS at provincial and city/regency level and LAZ at national, provincial and city/regency level in terms of collection, distribution, management and accountability of zakat.

The Zakat Management Act also provides guidance that collected zakat fund should be disbursed to eligible beneficiaries in the form of programs which consist of consumptive-based and productivebased programs. The term used in the Act to express consumptivebased program is distribution while for productive-based program, the Act uses utilization as its term. The former aims to provide resources which can fulfill short term needs of mustahik (zakat recipient) while the latter focuses on creating sustainable resources which fulfill long term needs of mustahik and elevates their level to become muzakki (zakat payers). The design of these two programs is expected to be able to realize two basic objectives of zakat management as stated in the Article 3 of the Act, that is: (i) to increase effectiveness and efficiency of services in zakat management; and (ii) to increase benefit of zakat in realizing society's welfare and poverty alleviation.

Nevertheless, one important issue that should be discussed further in the assessment of the success and the failure of the programs is the concept of poverty itself. Poverty is usually assessed from material perspective only. This could be observed from various research done by Jehle (1994), Shirazi (1996), Patmawati (2006), Beik (2009, 2013), Anriani (2010), Purnamasari (2010), and Beik and Tsani (2015). Their assessment mostly uses poverty headcount index, poverty depth index, poverty severity index and several inequality indices as analytical tools. They have provided significant contribution to the literature. However, research should not only stop on material aspect but also need improvement to cover spiritual aspect.

Therefore, the presence of instrument that accommodates both material and spiritual aspects of poverty is highly needed. Regarding this, Beik and Arsyianti (2015a) have attempted to construct tool of analysis that is related to poverty and welfare from material and spiritual perspectives in the form of CIBEST index. This index consists of welfare index, material poverty index, spiritual poverty index and absolute poverty index.

Given the background above, this study attempts to analyze the productive-based zakat programs which have been implemented by 
zakat institutions by using CIBEST index. The mustahik that will be observed are those managed by BAZIS DKI Jakarta, which is one of the most outstanding Provincial BAZNAS, and Dompet Dhuafa, which is the largest national LAZ. This study basically raises one research question that will be addressed, i.e. "what is the impact of productivebased programs of BAZIS DKI Jakarta and Dompet Dhuafa on the poverty and welfare level of the mustahik (zakat recipients)?".

This paper comprises five sections with introduction as the first one. Theoretical framework and previous studies will be discussed in the second section followed by research method in the third section. Fourth section will elaborate the findings and analysis while the last section concludes the paper.

\section{LITERATURE REVIEW}

\subsection{Theoretical Framework of CIBEST Model}

CIBEST model, which stands for Center of Islamic Business and Economic Studies, was designed and developed by Beik and Arsyianti (2015a). It is based on the conception that measuring poverty should be done in holistic and comprehensive way. It means that both material and spiritual aspects should be taken into consideration. This is in accordance with Islamic teaching derived from Al-Quran and Sunnah.

For example, the Quran Surah (QS) 20: 118-120 and QS 106: 34 elaborate several items considered as basic needs which must be fulfilled. According to Hafidhuddin (2013) these basic needs comprise the needs to perform worship; the needs on food, clothes and housing; and the needs to security and safety feeling. In this context, two fundamental basic needs are material basic needs and spiritual basic needs. Inability to fulfill these needs will place a person or a household under poor category, either materially poor, spiritually poor or both.

With regard to spiritual needs, the National Coordinating Agency for Family Planning Program (Badan Koordinasi Keluarga Berencana Nasional abbreviated as BKKBN) actually has included ability to fulfill spiritual needs as an indicator of Prosperous Family II, which is considered non poor family. This spiritual need could be observed 
from capability to perform worship regularly. Inability to perform it will place a household under pre-prosperous family or Prosperous Family I, which are considered poor according to BKKBN (Alimoeso, 2014).

The BKKBN concept obviously differs from the concept of Central Board of Statistics (BPS). BPS emphasizes on material aspect in which poverty is estimated based on per capita poverty line, which is derived from combination of food poverty line and non-food poverty line. Food poverty line is measured based on fulfillment of calorie need, which is minimum of 2,100 kcal per capita per day. M eanwhile, the non-food poverty line is calculated based on fulfillment of several commodities of basic needs. These commodities are based on geographical location, in which there are 47 commodities calculated for rural areas and 51 commodities estimated for urban area (BPS, 2014a).

In the CIBEST Model, Beik and Arsyianti (2015a) use household as unit of analysis and divide the household into four possible situations with regard to their ability in fulfilling material and spiritual needs. Firstly, a household is able to fulfill both needs, i.e. material and spiritual needs completely. This is called as prosperous household. They live under hayatan thayyibah or welfare condition as mentioned by Allah SWT in the QS 16: 97.

Secondly, a household has capacity to fulfill spiritual needs only, while they are unable to fulfill material needs up to the minimum level. This household lives under material poverty. This is in line with the statement of Allah in the QS 2: 155-156. In these verses Allah has provided information that some people will be tested with lack of wealth, lack of fruits and other material needs. In other words, these people live under material deficiency condition. However, they have strong spiritual condition, which is indicated by their commitment to always surrender themselves to Allah and to maintain their patience and fortitude in the way of Allah. They may suffer in this world, but they will be rewarded by Allah in the hereafter.

Thirdly, as the opposite of the second one, a household is able to fulfill only material needs. As for spiritual needs, this household has no capability to fulfill it. This household basically lives under spiritual poverty condition. Regarding this, Allah SWT has mentioned this kind of people in the QS 6: 44. In this verse, Allah describes the presence of 
group of people who are intentionally unfollowing Allah's commandment. However, they are able to earn abundance of wealth and money to support their life. They may be getting pleasure in this world, but surely getting suffered in the hereafter if they do not change their spiritual condition.

Fourthly, a household is not able to fulfill both material and spiritual needs. This household lives under the category of absolute poverty. This has been described by Allah in the QS 20: 124. Those who live under absolute poverty are the most unfortunate people suffering in this world and in the hereafter. Therefore, this group of people should be given more attention in the development process of the country as they represent the weakest group of the society.

Based on this conception and typology of household, Beik and Arsyianti (2015a) construct formula to compute welfare index, material poverty index, spiritual poverty index and absolute poverty index which are derived from CIBEST quadrant. This quadrant is based on the typology of household discussed above (Figure 1).

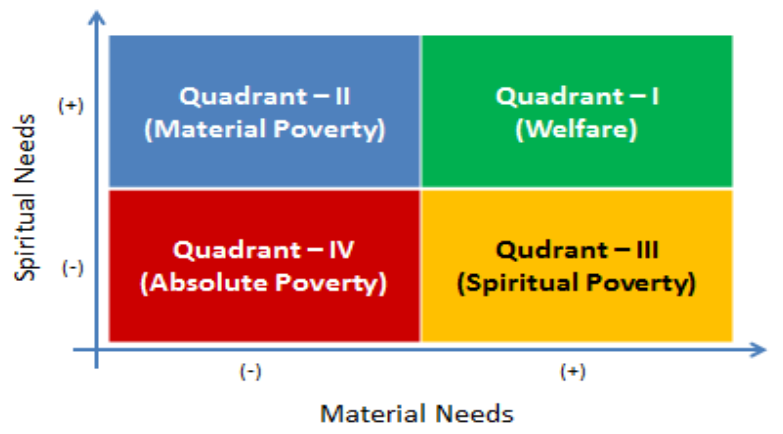

Figure 1.

CIBEST Quadrant

Source: Beik and Arsyianti (2015a)

Based on the Figure 1, CIBEST quadrant is divided into four quadrants. A household staying in the first quadrant is considered as materially and spiritually rich household. It is because the household can positively fulfill both material and spiritual needs. By using the same analysis, it is known that in the second quadrant, the household is materially poor and spiritually rich. Meanwhile the third quadrant 
indicates that the household staying in the quadrant is materially rich and spiritually poor, while the fourth quadrant portrays the household that is materially and spiritually poor. Sufficiency in fulfilling the needs also means that the household live above the poverty line, either material poverty line, spiritual poverty line or both lines (Beik \& Arsyianti, 2015a).

Beik and Arsyianti (2015b) further argue that determination of material poverty line may be based on three approaches. Firstly, it is based on the periodic survey on the minimum basic material needs. Secondly, standard of poverty line created by the Central Board of Statistics may be used with modification and adjustment, from per capita approach to household approach. Thirdly, standard of nisab (exemption limit) of zakat of profession or income may be used as the last alternative. It is because the nisab line is the standard separating muzakki and mustahik.

As for spiritual needs, Beik and Arsyianti (2015b) argue that it should be based on three groups of variable comprising worship, household environment and government policy. Worship group consists of three variables, i.e. prayer, fasting and sharing (zakat and infaq), which are obligatory worship in the shariah perspective. Inability to fulfill these worships may reduce spiritual condition of the household and hence, may put them in the spiritual poverty.

The inclusion of household environment and government policy is because these two variables have strong influence towards commitment of household members to perform their worship (ibadah) as well as associated with a sense of security and freedom in performing the worship (Beik \& Arsyianti, 2015b). Specifically, Table 1 provides the details and indicators of these spiritual needs. 
Table 1.

Spiritual Needs Indicator

\begin{tabular}{|c|c|c|c|c|c|c|}
\hline \multirow{2}{*}{ Variables } & \multicolumn{5}{|c|}{ Likert Scale } & \multirow{2}{*}{$\begin{array}{l}\text { Poverty } \\
\text { Standard }\end{array}$} \\
\hline & 1 & 2 & 3 & 4 & 5 & \\
\hline Prayer & $\begin{array}{l}\text { Blocking } \\
\text { others to } \\
\text { pray }\end{array}$ & $\begin{array}{l}\text { Against } \\
\text { the } \\
\text { concept of } \\
\text { prayer }\end{array}$ & $\begin{array}{l}\text { Performing } \\
\text { obligatory } \\
\text { prayer but } \\
\text { not on } \\
\text { regular basis }\end{array}$ & $\begin{array}{l}\text { Always } \\
\text { performing } \\
\text { obligatory } \\
\text { prayer but } \\
\text { not in } \\
\text { congregati- } \\
\text { onal prayer }\end{array}$ & $\begin{array}{l}\text { Performing } \\
\text { congregati- } \\
\text { onal prayer for } \\
\text { obligatory one } \\
\text { and perform } \\
\text { recommended } \\
\text { prayer }\end{array}$ & \multirow{5}{*}{$\begin{array}{l}\text { Average } \\
\text { score for } \\
\text { spiritually } \\
\text { poor } \\
\text { household } \\
\text { is equal to } \\
3 \\
\text { (SV = 3) }\end{array}$} \\
\hline Fasting & $\begin{array}{l}\text { Blocking } \\
\text { others to } \\
\text { undertak } \\
\text { e fasting }\end{array}$ & $\begin{array}{l}\text { Against } \\
\text { the } \\
\text { concept of } \\
\text { fasting }\end{array}$ & $\begin{array}{l}\text { Not fully } \\
\text { performing } \\
\text { obligatory } \\
\text { fasting }\end{array}$ & $\begin{array}{l}\text { Performing } \\
\text { only } \\
\text { obligatory } \\
\text { fasting }\end{array}$ & $\begin{array}{l}\text { Performing } \\
\text { obligatory } \\
\text { fasting and } \\
\text { recommend- } \\
\text { able fasting }\end{array}$ & \\
\hline $\begin{array}{l}\text { Zakat and } \\
\text { Infak }\end{array}$ & $\begin{array}{l}\text { Blocking } \\
\text { others to } \\
\text { pay zakat } \\
\text { and infak }\end{array}$ & $\begin{array}{l}\text { Against } \\
\text { the } \\
\text { concept of } \\
\text { zakat and } \\
\text { infak }\end{array}$ & $\begin{array}{l}\text { Not paying } \\
\text { infak at } \\
\text { least once in } \\
\text { a year }\end{array}$ & $\begin{array}{l}\text { Paying zakat } \\
\text { al-fitrand } \\
\text { zakat al-maal }\end{array}$ & $\begin{array}{l}\text { Paying zakat } \\
\text { al-fitr, zakat al- } \\
\text { maal, and } \\
\text { infak }\end{array}$ & \\
\hline $\begin{array}{l}\text { Household } \\
\text { Environ- } \\
\text { ment }\end{array}$ & $\begin{array}{l}\text { Forbid } \\
\text { ibaadah }\end{array}$ & $\begin{array}{l}\text { Against } \\
\text { implemen- } \\
\text { tation of } \\
\text { ibaadah }\end{array}$ & $\begin{array}{l}\text { Consider } \\
\text { ibaadah as } \\
\text { private } \\
\text { matter for } \\
\text { household } \\
\text { member } \\
\end{array}$ & $\begin{array}{l}\text { Support } \\
\text { execution of } \\
\text { ibaadah }\end{array}$ & $\begin{array}{l}\text { Creating } \\
\text { environment } \\
\text { which } \\
\text { obligates } \\
\text { execution of } \\
\text { ibaadah } \\
\end{array}$ & \\
\hline $\begin{array}{l}\text { Govern- } \\
\text { ment Policy } \\
\text { Environ- } \\
\text { ment }\end{array}$ & $\begin{array}{l}\text { Forbid } \\
\text { ibaadah }\end{array}$ & $\begin{array}{l}\text { Against } \\
\text { implemen- } \\
\text { tation of } \\
\text { ibaadah }\end{array}$ & $\begin{array}{l}\text { Consider } \\
\text { ibaadah as } \\
\text { private } \\
\text { matter }\end{array}$ & $\begin{array}{l}\text { Support } \\
\text { execution of } \\
\text { ibaadah }\end{array}$ & $\begin{array}{l}\text { Creating } \\
\text { environment } \\
\text { which } \\
\text { obligates } \\
\text { execution of } \\
\text { ibaadah } \\
\end{array}$ & \\
\hline
\end{tabular}

Source: Beik and Arsyianti (2015a)

\subsection{Previous Studies}

A number of researches have attempted to measure the impact of zakat on reduction of poverty and income inequality. Jehle (1994) for instance, attempted to examine the impact of zakat on income inequality in Pakistan. Employing AKS (Atkinson Kolm \& Sen) index of inequality, Jehle constructed two types of income distribution by using data from 1987-1988 - one that would have been obtained if zakat had not been given, and one that could have attained.

As compared to Atkinson's index, which uses the degree of inequality aversion, AKS index utilizes the ethical indices of inequality to gauge the overall effect. Jehle found that no income group received even a quarter of one percent of its total income through zakat. The 
mean annual income of the contributors was 447 rupees, above the country's mean income of 413 rupees. But the mean for recipients was 410 rupees, which indicated that zakat's main function was to transfer resources from one segment of the middle class to the less well-off segment. The result showed that zakat did reduce measured income inequality in Pakistan and suggested that both intra-province and inter-province components of overall inequality fell very marginally (Jehle, 1994).

Still in the case of Pakistan, Shirazi (1996) examined the impact of zakat and 'ushr on poverty alleviation in the country. By using FGT (Foster, Greer and Thorbecke) index, he found that in 1990-1991, 38 percent of all Pakistani's households stood under their country's official poverty line, but figure would have been slightly higher, 38.7 percent in the absence of obligatory and voluntary zakat transfer. He also found that the poverty gap had fallen from 11.2 percent to 8 percent with the existence of the voluntary zakat transfers. His study also suggested that zakat had no significant impact on the average disposable income of any income deciles but the lowest.

Furthermore, Patmawati (2006) studied the impact of zakat on poverty reduction in Selangor State, Malaysia. By employing household-count ratio, average poverty gap, income gap, Sen Index, and FGT (Foster, Greer and Thorbecke) Index, Patmawati's analysis revealed that zakat distribution was able to reduce poverty incidence, reduce the depth of poverty and narrowed the severity of poverty in the state.

In the case of Indonesia, studies conducted by Beik (2009, 2013), Anriani (2010), Purnamasari (2010), and Beik and Tsani (2015) are worth mentioning. Beik (2013) for example, concluded that zakat distribution programs conducted by the National Board of Zakat (BAZNAS), BAZIS DKI Jakarta and Dompet Dhuafa in the area of Greater Jakarta were able to decrease the poverty incidence by an average of 16.79 percent. The depth of poverty could also be reduced as the poverty gap and the income gap showed the reductions of 13.90 percent and 13.72 percent, respectively. Similarly, the severity of poverty could also be lowered as evidenced from a 26.69 percent increase in the Sen Index and a 36.70 percent increase in the FGT index. 
Similar findings were also found by Anriani (2010), Purnamasari (2010) and Beik and Tsani (2015) although with different location of studies. Anriani (2010) has found that poverty incidence in Bogor city could be reduced by 8.77 percent in the presence of zakat distribution and utilization programs, while in the case of Garut regency and South Lampung regency, this poverty incidence could be decreased by 21.40 percent and 18.60 percent as evidenced from Purnamasari (2010) and Beik and Tsani (2015), respectively.

Those studies also revealed the fact that the presence of zakat distribution programs in the form of consumptive-based and productive-based programs was able to reduce the depth of poverty and the severity of poverty significantly. These results provided evidence on the importance of the role of formal amil institution in managing zakat fund efficiently and effectively

\section{METHODOLOGY}

\subsection{Type of Data and Location of Research}

Data used in this study consists of primary data and secondary data. Primary data is obtained from interview and questionnaire to the mustahik (zakat recipient) that is managed by BAZIS DKI Jakarta and Dompet Dhuafa. The primary data collection was conducted from February 2015 to May 2015 in Jakarta and Bogor. As for secondary data, it is obtained from literature survey.

\subsection{Population and Sample}

Population of this research is defined as the mustahik participating in the productive-based zakat programs of BAZIS DKI Jakarta and Dompet Dhuafa and these mustahik live in Jakarta and Bogor regency. Total number of population is equal to 4,823 people.

From this number of population, this study selects 221 people as sample or 4.60 percent from total population. 121 samples are mustahik of Dompet Dhuafa and the remaining 100 samples are mustahik of BAZIS DKI Jakarta. These samples were selected by using purposive sampling technique.

Male respondents (81.90 percent) seem to be dominant compared to female respondents (18.10 percent). Most of the 
respondents, i.e. 54.75 percent, are living in Bogor regency while the remaining 45.25 percent of the respondents are residing in Jakarta.

\subsection{Method of Data Analysis}

In applying this CIBEST Model, Beik and Arsyianti (2015b) have provided several stages of calculation that must be followed:

1. Determination of material poverty line and spiritual poverty line

Material poverty line (symbolized by MV) is derived from the following formula:

$$
M V=\sum_{i=1}^{n} P_{i} M_{i}
$$

whereby:

$M V=$ minimum material needs standard (in terms of Rp or local currency)

$P_{i} \quad=$ price of goods and services $\mathrm{i}$ (in terms of Rp or local currency)

$M_{i}=$ minimum number of goods and services i needed

This research in determining the value of MV uses BPS standard of poverty line and modifies the standard. Since Jakarta and Bogor regency are selected, the study uses two poverty lines, i.e. Jakarta poverty line and Bogor regency poverty line, as of September 2014.

Jakarta poverty line used is Rp459,560.00/per capita/month while Bogor regency poverty line used is Rp300,119.00/per capita/month. Since CIBEST model requires household as unit of analysis, this per capita poverty line should be transformed into household poverty line. It is done by multiplying the poverty line with average household member in Jakarta and Bogor regency, respectively.

According to BPS (2014b), the average household member in Jakarta and Bogor regency is similar, i.e. equal to 3.9 persons / household. By multiplying it with the poverty line, the MV values can be calculated as follow:

$M V j=\operatorname{Rp~459,560.00~} \times 3.9=\operatorname{Rp} 1,792,284.00 /$ household/month $M V b=R p 300,119.00 \times 3.9=$ Rp 1,170,464.10/household $/$ month whereby: 
$M V j=$ modified Jakarta poverty line

$\mathrm{MVb}=$ modified Bogor regency poverty line

As for spiritual poverty line (symbolized by SV) it is equal to 3 $(\mathrm{SV}=3)$. It has also been portrayed in the Table 1 .

2. Calculation of spiritual score of the observed household prior to and after joining the productive-based zakat programs

General formula to compute spiritual score of the observed household is as below:

$$
S S=\sum_{k=1}^{n} \frac{S H_{k}}{N}
$$

whereby:

$S S=$ average score of actual spiritual condition of all observed households

$S H_{k}=$ actual spiritual score of household $k$

$N=$ total number of observed households

As for the value of $S H$, it is obtained by applying the following formula:

$$
S H=\sum_{i=1}^{n} \frac{H_{1}+H_{21}+\cdots+H_{1 n}}{M H}
$$

whereby:

SH = average score of actual spiritual condition of one household

$H_{i}=$ actual spiritual score of household member $i$

$M H=$ total number of household members

As for $H_{i}$, its formula is as below:

$$
H_{i}=\frac{V p_{i}+V f_{i}+V z_{i}+V h_{i}+V g_{i}}{5}
$$

whereby:

$H_{i}=$ actual spiritual score of household member $i$

$V p_{i}=$ prayer score of household member $i$

$V f_{i}=$ fasting score of household member $i$ 
$V z_{i}=$ score of zakat and infak of household member $i$

$V h_{i}=$ score of household environment based on perception of household member $i$

$V g_{i}=$ score of government policy environment based on perception of household member $i$

3. Calculation of actual income or expenditure of the observed households

This is important in order to determine whether their income or expenditure exceed the value of MV or not. Through this stage it will be known whether the household is materially rich or poor.

\section{Grouped into CIBEST quadrant}

After having the values of MV, SV, actual score of spiritual and real income or expenditure of the observed households, then each household is grouped into the CIBEST quadrant by using the combination of their spiritual and material scores (vide Table 2).

Table 2.

\section{Combination of MV and SV Values}

\begin{tabular}{|c|c|c|}
\hline Results & $\leq$ MV value & $>$ MV value \\
\hline >SV value & Materially Poor and Spiritually & Materially and Spiritually Rich \\
& Rich Household & Household \\
& (Quadrant II) & (Quadrant I) \\
\hline S SV value & Materially and Spiritually Poor & Materially Rich and Spiritually Poor \\
& Household & Household \\
& (Quadrant IV) & (Quadrant III) \\
\hline
\end{tabular}

5. Calculation of each quadrant in order to obtain the values of welfare index, material poverty index, spiritual poverty index and absolute poverty index, respectively

The formula of those indices is as below:

$$
W=\frac{w}{N}
$$

whereby:

$W=$ welfare index $(0 \leq W \leq 1)$

$w$ = the number of spiritually and materially rich households

$N=$ the total number of observed households 


$$
P m=\frac{M p}{N}
$$

whereby:

$P m=$ material poverty index $(0 \leq P m \leq 1)$

$M p=$ the number of materially poor and spiritually rich households

$N=$ the total number of observed households

$$
P S=\frac{S p}{N}
$$

whereby:

$P s=$ spiritual poverty index $0 \leq P s \leq 1$

$S p=$ the number of spiritually poor and materially rich households

$N=$ the total number of observed households

$$
P a=\frac{A p}{N}
$$

whereby:

$P a=$ absolute poverty index $(0 \leq P a \leq 1)$

$A p=$ the number of spiritually and materially poor households

$N=$ the total number of observed households

\section{RESULT AND ANALYSIS}

To analyze the impact of productive-based zakat programs of BAZIS DKI Jakarta and Dompet Dhuafa, Table 3 below provides the spiritual score of the observed households.

From the Table 3, it is found that both BAZIS DKI Jakarta and Dompet Dhuafa have selected their mustahik whose spiritual condition is already good. This could be observed from the pre-zakat programs spiritual score which equals 3.82. It means that in general, they are already above spiritual poverty line. After the execution of the program, the spiritual score of the mustahik can be increased to 4.32 . It increases by 13.09 percent. 
Table 3.

Average Spiritual Score of the Mustahik Households

\begin{tabular}{|c|c|c|}
\hline \multirow[t]{2}{*}{ Variable } & \multicolumn{2}{|c|}{ Average Spiritual Score } \\
\hline & $\begin{array}{c}\text { Pre-Zakat Program } \\
\left(\mathrm{SS}_{1}\right)\end{array}$ & $\begin{array}{c}\text { Post-Zakat Program } \\
\left(\mathrm{SS}_{2}\right)\end{array}$ \\
\hline Shalat (Prayer) & 3.55 & 3.93 \\
\hline Fasting & 4.00 & 4.37 \\
\hline Zakat and Infaq & 3.92 & 4.67 \\
\hline Household Environment & 3.66 & 4.20 \\
\hline Government Policy & 3.95 & 4.40 \\
\hline $\begin{array}{c}\text { Average Spiritual Score of } \\
\text { Total Observed } \\
\text { Households }\end{array}$ & 3.82 & 4.32 \\
\hline
\end{tabular}

Furthermore, since the income or expenditure of the observed households is known, each household is grouped to CIBEST quadrant by combining with their spiritual score. The following Figure 2 portrays the results.

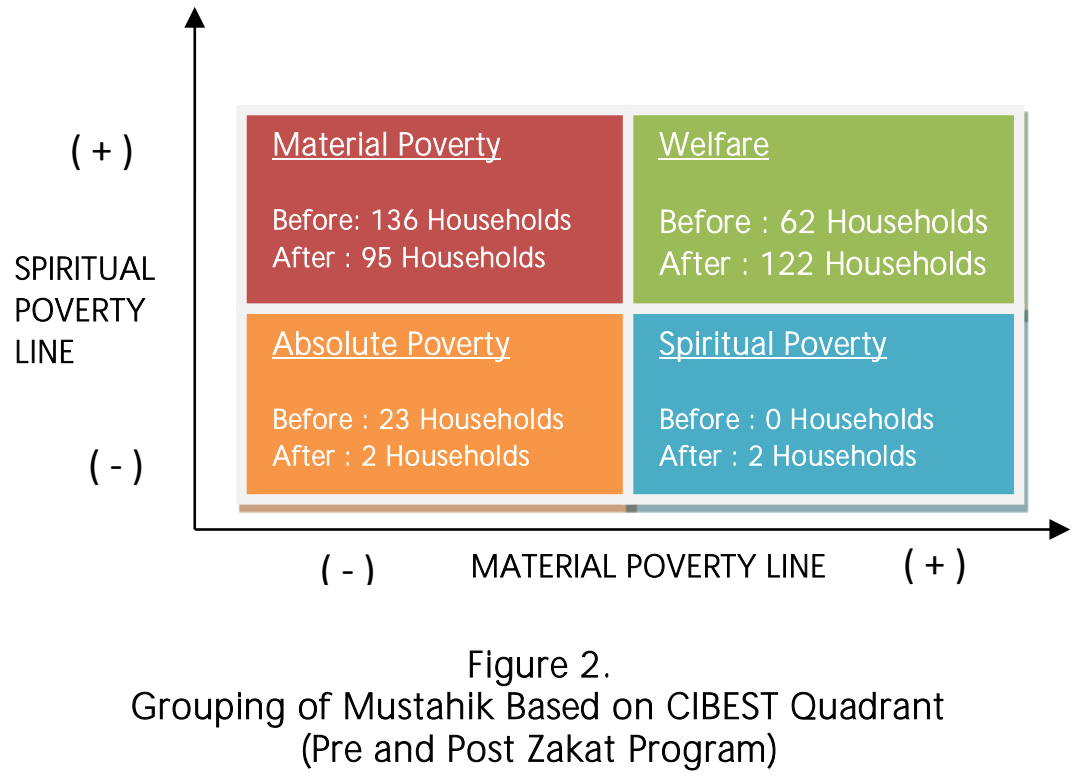

Source: Primary Data (processed)

From the Figure 2 it is found that majority of the households is in the second quadrant (136 households) prior to productive-based zakat programs. However, 62 households are already in the first 
quadrant meaning that they are already better-off. There are only 23 households who are in the fourth quadrant and none in the third quadrant.

After the program is conducted, the number of households living in the first quadrant increases to 122 households. This is as the results of migration of household from second quadrant and fourth quadrant. The number of households in those quadrants is now equal to 95 households and 2 households, respectively. However, it is interesting to note that there are 2 households moving from the fourth quadrant to the third quadrant. It means that after receiving zakat fund and other technical assistance, their spiritual condition decreases. It should encourage BAZIS DKI Jakarta and Dompet Dhuafa to pay more attention to the possibility of decreasing spiritual condition.

Finally, the values of all indices can be calculated. The results can be found in the Table 4 below.

Table 4.

CIBEST Index: Pre and Post Zakat Program

\begin{tabular}{cccc}
\hline CIBEST Index & $\begin{array}{c}\text { Pre Zakat } \\
\text { Program }\end{array}$ & $\begin{array}{c}\text { Post Zakat } \\
\text { Program }\end{array}$ & $\begin{array}{c}\text { Percentage } \\
\text { Change }\end{array}$ \\
\hline Material Poverty Index & 0,615 & 0,430 & $-30,15$ \\
Spiritual Poverty Index & 0 & 0,009 & +100 \\
Absolute Poverty Index & 0,104 & 0,009 & $-91,3$ \\
Welfare Index & 0,281 & 0,552 & 96,8 \\
\hline
\end{tabular}

Source: Primary Data (processed)

Based on the Table 4, it can be concluded that in general productive-based zakat programs conducted by BAZIS DKI Jakarta and Dompet Dhuafa can increase welfare level of the mustahik by 96.8 percent. Similarly, material poverty index and absolute poverty index can also be reduced by 30.15 percent and 91.30 percent, respectively. Exception is on the spiritual poverty index which shows an increase of 100 percent. As has been highlighted before, it is due to an increase in the number of households living in this quadrant from none to two households. It can be said that it is outlier result.

Most of the mustahik are of the view that they are really helped with the presence of productive-based zakat programs which were 
introduced by BAZIS DKI Jakarta and Dompet Dhuafa. The programs have assisted the mustahik in getting sustainable sources of income in the form of micro and small business that they can manage. Services provided by these two zakat institutions are satisfying the mustahik.

Significant increase in the welfare index indicates that zakat can be used as instrument to alleviate poverty and increase welfare condition of the poor. Government should utilize zakat and integrate it with the policy on poverty. The results also provide evidence that when zakat is managed by trustable and professional institution, its impact towards condition of the poor in particular and national economy in general will be very high and significant.

\section{CONCLUSION AND RECOMMENDATION}

\subsection{Conclusion}

Based on the findings of this study, it can be concluded that the presence of productive-based zakat programs of BAZIS DKI Jakarta and Dompet Dhuafa has given significant impact to the condition of the mustahik. The spiritual score of the mustahik is found to be increased by 13.09 percent.

The results also show that welfare index can be increased by 96.8 percent and material poverty index as well as absolute poverty index can be lowered by 30.15 percent and 91.30 percent, respectively. Exception is only on spiritual poverty index, which indicates an increase of 100 percent.

\subsection{Recommendation}

Given these results, there are three recommendations that can be the follow-up from this research. Those are:

1. BAZIS DKI Jakarta and Dompet Dhuafa should increase their monitoring program in order to anticipate the households suffering degradation in their spiritual condition. Evaluation of education and spiritual assistance to the zakat recipients should be enhanced.

2. The government should integrate zakat in more serious effort to the national economic policy as the two observed zakat institutions has shown remarkable performance in reducing 
poverty level of the mustahik.

3. This study focuses only on productive-based zakat programs. Further research on consumptive-based zakat programs and on other zakat institutions in wider areas of study are highly recommended as an effort to prove the significant role played by zakat instrument. 


\section{REFERENCES}

Alimoeso, S. (2014). Pemanfaatan data keluarga dalam pembangunan keluarga. Paper presented at National Seminar of BAZNAS, Balikpapan.

Anriani. (2010). Analisis dampak zakat terhadap tingkat kemiskinan mustahik (Studi kasus: Pendayagunaan zakat oleh BAZ Kota Bogor di tiga kecamatan Kota Bogor) (Undergraduate Thesis). Bogor Agricultural University, Indonesia.

Badan Amil Zakat Nasional (The National Board of Zakat of Indonesia). (2013). Laporan zakat edisi milad BAZNAS ke-12. Jakarta: Author.

Beik, I. S. (2009). Analisis peran zakat dalam mengurangi kemiskinan: studi kasus Dompet Dhuafa Republika. Zakat \& Empowering Jurnal Pemikiran dan Gagasan, 2. Retrieved from http://imz.or. id/new/uploads/2011/10/Analisis-Peran-Zakat-dalam-M engu rangi-Kemiskinan.pdf

Beik, I. S. (2013). Economic role of zakat in reducing poverty and income inequality: A case study in the Province of DKI Jakarta, Indonesia. LAP Lambert Academic Publishing.

Beik, I. S., \& Arsyianti, L. D. (2015a). Construction of CIBEST model as measurement of poverty and welfare indices from Islamic perspective. Al-lqtishad: Journal of Islamic Economics, 7(1): 87104. Retrieved from http://doi.org/10.15408/ijies.v7i1.1361

Beik, I. S., \& Arsyianti, L. D. (2015b). Ekonomi pembangunan syariah. Bogor: IPB Press.

Beik, I.S., \& Tsani, T. (2015). Role of zakat distribution in reducing poverty and income inequality in Indonesia. In M. M. Mohd Yusop \& N. Abdullah (Eds.), Zakat and Poverty Alleviation (pp.198-217). Kuala Lumpur: IIUM Press.

Badan Pusat Statistik. (2013). Statistik Indonesia. Jakarta: Author.

Badan Pusat Statistik. (2014a). Berita resmi statistik (Official statistic news). Jakarta: Author. 
Badan Pusat Statistik. (2014b). Jumlah dan presentase penduduk miskin, garis kemiskinan, Indeks Kedalaman Kemiskinan (P1), dan Indeks Keparahan Kemiskinan (P2), menurut provinsi edisi September 2014. Jakarta: Author.

Badan Pusat Statistik. (2015). Berita resmi statistik (Official statistic news). Jakarta: Author.

Badan Pusat Statistik Kabupaten Bogor. (2013). Penyusunan perencanaan target indikator ekonomi daerah Kabupaten Bogor tahun 2014-2018 (Laporan Akhir). Bogor: Author.

Firdaus, M., Beik, I. S., Irawan, T. \& Juanda, B. (2012). Economic estimation and determinations of zakat potential in Indonesia (IRTI Working Paper Series WP 1433-07, August). Retrieved from http://www.irti.org/English/Research/Documents/334.pdf

Hafidhuddin, D. (2013). Analisis syariah tentang konsep kemiskinan. Paper presented at National Focus Group Discussion on Islamic Poverty Line, Bogor.

Jehle, G. A. (1994). Zakat and inequality: Some evidence from Pakistan. Review of Income and Wealth, Series 40, No.2, June.

Patmawati. (2006). Economic role of zakat in reducing income inequality and poverty in Selangor (Doctoral Thesis). Universiti Putra M alaya, Selangor.

Purnamasari, N. (2010). Analisis pengaruh pendayagunaan zakat, infaq, dan shadaqah terhadap pengurang kemiskinan (Studi kasus: Pusat zakat umat LAZ Persis Garut) (Undergraduate Thesis). Bogor Agricultural University, Indonesia

Qardawi, Y. (2011). Hukum zakat. Jakarta: Litera Antarnusa.

Shirazi, N. S. (1996). System of zakat in Pakistan: An appraisal. Islamabad: International Institute of Islamic Economics.

Undang-Undang Republik Indonesia Nomor 23. (2011). Pengelolaan zakat. Jakarta, 25 November 2011. 